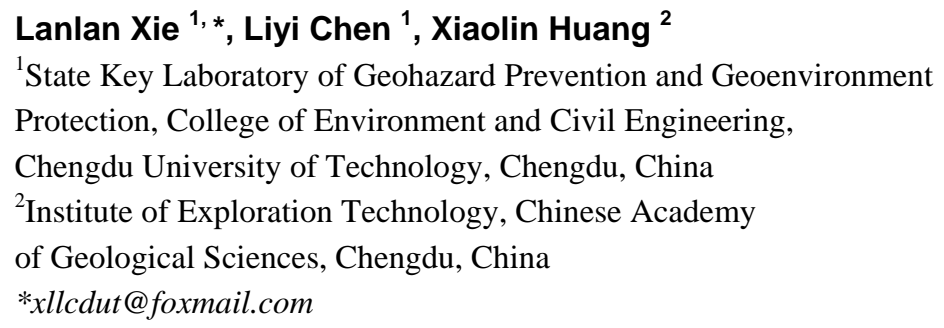

\title{
Effect of graphite addition on impregnated diamond bit properties
}

Graphite was used as a solid lubricant to reduce thermal damage in diamond bit when drilling without coolant. Graphite was added to the bit matrix material to reduce friction coefficient and heat. The influence of content, granularity, and surface metallization of graphite on the mechanical property and dry friction properties of the matrix, as well as the effect of diamond lifetime in the working layer were studied. Results showed that the hardness, bending strength, and friction coefficient of matrix gradually decreased with the increase in graphite concentration. Meanwhile, the abrasion loss decreased first and then increased, and the lifetime of diamond in the working layer gradually increased. With the decrease in graphite granularity, the bending strength and friction coefficient of matrix gradually decreased, whereas the hardness, abrasion loss of matrix, and diamond lifetime in the working layer gradually increased. After surface metallization of graphite, the hardness, bending strength, friction coefficient, and abrasion loss of matrix increased, whereas the lifetime of diamond in the working layer decreased. This study lays a foundation for drilling without water.

Keywords: graphite, diamond bit, mechanical property, dry friction properties, lifetime of diamond.

\section{INTRODUCTION}

A long-term prospecting practice indicated that diamond drilling is efficient [1]. However, bit burnt accidents frequently occur due to the thermal damage of diamond, which seriously affects geological exploration. In the drilling process, the reduction of diamond heat damage is achieved by the cooling action and lubrication effect of drilling fluid [2]. However, cooling the diamond bit is difficult in areas without water, such in the dry regions of western China or in the outer space [3].

Graphite is widely applied as a solid lubricant in grinding because of its remarkable lubrication effect. Whether added to a grinding wheel or composite material, or used as a coating, graphite could reduce the friction factor of the friction pairs [4-9]. And the content and granularity of solid lubricant influence the dry friction properties of composites. The influence on $\mathrm{NiCr}-\mathrm{Cr}_{2} \mathrm{O}_{3}-\mathrm{Ag}$ composites, Cu-based P/M friction composites and graphite - PTFE dry lubrication system is known [10-12]. When graphite is in the soft phase form in composite materials, the dry tribological properties of composites are improved; however, their mechanical properties, such as hardness and bending strength, are reduced [3]. In the present study, graphite particles were coated with nickel by 
electroplating with optimum technology, as described previously [13]. The nickelcoated graphite particles were then added to the bit matrix to improve the compatibility of graphite and matrix material.

Then, graphite is added to the working layer of bit to make graphite-diamond composite material, and its structure and properties are studied. A lot of works have been devoted to the study of the properties of composite diamond-containing materials based on metal matrices containing iron, copper, nickel, tin, tungsten carbide, cobalt, obtained by powder metallurgy methods. The most significant scientific and practical results on the formation of the structure of such composites with improved mechanical characteristics were obtained in [14-23]. The positive influence of chromium diboride (CrB2) [24-27], tungsten carbide (WC) [28] and vanadium nitride [29] on the structure and properties of composites is known. The properties of these composites are determined by the composition, structure and morphology, which, in turn, depend on the properties of their constituents, methods and modes of sintering. Some important properties of composites vary depending on the force parameters of rock failure [30], contact temperatures [31-34], stressstrain state of the matrix $[35,36]$, as well as placement of composites on the tool working surface [37]. Nevertheless, in these works the influence of the graphite addition on the mechanical and tribological properties of the composites under consideration is not taken into account.

This study mainly investigated the influence of content, granularity, and surface metallization of graphite on the mechanical properties (i.e., hardness and bending strength, dry friction and wear properties) of the composite material, and lifetime of diamond in the working layer.

\section{EXPERIMENTAL}

The basic formula of the matrix was $18 \mathrm{wt} \% \mathrm{WC}, 9 \mathrm{wt} \%$ nickel, $3 \mathrm{wt} \%$ cobalt, $5 \mathrm{wt} \%$ manganese, $35 \mathrm{wt} \%$ bronze (663), and $30 \mathrm{wt} \%$ Fe. The basic formula of the working layer was unchanged, in which $20 \mathrm{vol} \%$ (8.6 wt \%) diamond was added, and particle size of the diamond was 50/60 mesh. Samples were prepared by hot pressing-sintering method under the following conditions: $945^{\circ} \mathrm{C}$ sintering temperature, $15 \mathrm{MPa}$ pressure, and 3 min holding time. The sample design is shown in Table.

\section{Sample design table}

\begin{tabular}{c|c|c|c|c}
\hline $\begin{array}{c}\text { Sample } \\
\text { of matrix }\end{array}$ & $\begin{array}{c}\text { Granularity } \\
\text { of graphite } \\
\text { (mesh) }\end{array}$ & $\begin{array}{c}\text { Content } \\
\text { of graphite } \\
\text { (wt \%) }\end{array}$ & $\begin{array}{c}\text { Weight gain } \\
\text { of graphite after } \\
\text { metallization (wt \%) }\end{array}$ & $\begin{array}{c}\text { Sample } \\
\text { of working layer } \\
\text { (with diamond) }\end{array}$ \\
\hline 1 & \multicolumn{5}{c}{$\begin{array}{l}1^{\prime} \\
2\end{array}$} & 0 & 0 & $2^{\prime}$ \\
3 & $100 / 120$ & 0.6 & 0 & $3^{\prime}$ \\
4 & $100 / 120$ & 1.2 & 0 & $4^{\prime}$ \\
5 & $100 / 120$ & 1.8 & 0 & $5^{\prime}$ \\
6 & $100 / 120$ & 2.4 & 0 & $6^{\prime}$ \\
7 & $40 / 60$ & 1.2 & 0 & $7^{\prime}$ \\
8 & $60 / 80$ & 1.2 & 0 & $8^{\prime}$ \\
9 (with nickel- & $80 / 100$ & 1.2 & 36.36 & $9^{\prime}$ \\
plated graphite) & $80 / 100$ & 1.2 & & $10^{\prime}$ \\
10 (with nickel- & $80 / 100$ & 1.2 & 45.35 & \\
plated graphite) & & &
\end{tabular}


Three-point bending method was adopted to test the bending strength of the sample on the WE-30 hydraulic universal material test machine, and the pressurevelocity was $100 \mathrm{~N} / \mathrm{s}$. A sample of every formula was tested for five times, of which the average was calculated as bending strength. An HR-150A Rockwell apparatus was used for hardness test, and the sample of every formula was broken down into three pieces. Every sample was tested at six points, and then the average value of the 18 test points was obtained as the hardness.

Friction and wear between the sample and granite were analyzed by the MG2000A friction and wear test machine, the contact form is plate-on-plate, and the type of relative motion is circled. The pressure was $2 \mathrm{MPa}$, the rotation rate was $0.94 \mathrm{~m} / \mathrm{s}$, and the time of dry friction was $10 \mathrm{~min}$, the total distance of the relative motion was $565 \mathrm{~m}$. The wear resistance was measured by the quality loss before and after the friction and wear test. The sample was washed by distilled water, dry by oven, and weigh by the electronic scale with accuracy of $0.001 \mathrm{~g}$. The friction coefficient was calculated by using the software of the MG-2000A friction and wear test machine. There is initial run-in period in the friction coefficient curve, and then become stability. Friction coefficient of a sample is the average of the steady-state sliding period. And the calculation formula is as follows:

$$
\mu=\frac{\sum \frac{M}{R N}}{n},
$$

where $\mu$ is friction coefficient; $M$ is friction torque, $\mathrm{N} \cdot \mathrm{m} ; N$ is positive pressure, $\mathrm{N}$; $R$ is radius of rotation, which is $0.03 \mathrm{~m}$; and $n$ is sampling number of the steadystate sliding period.

The sample of every formula was broken down into three pieces, and the value is the average of the three.

The interface between the graphite particles and matrix on the fracture surface of the sample after bending strength test and the surface morphology of the sample after friction and wear test were observed by Quanta 200 type environmental scanning electron microscope. After friction and wear test, the surface of the sample was analyzed by energy spectrum.

\section{RESULTS AND DISCUSSION}

\section{Binding properties of graphite and matrix}

Figure 1 is the SEM image of the interface between graphite and matrix. Figure 1, $a$ shows the SEM image of sample 8 with pure graphite, while Fig. 1, $b$ shows the SEM image of sample 10 with nickel-plated graphite. A large space between graphite and matrix is observed, and the anchoring effect between them is very weak in sample 8 . No reaction, dissolution, or wettability was observed between graphite and matrix. This finding can be attributed to the relatively stable chemical properties of graphite and the absence of metallurgical effect on the matrix material at sintering temperature. In addition, the interface energy of graphite is relatively low; thus, wetting by matrix materials at high sintering temperature is difficult. However, no evident gap is observed between the nickelplated graphite particles and the matrix material in sample 10, which indicates that their interface bonding is close.

After plating, nickel can be evenly distributed over the entire surface of the graphite particles, even in the dent on the surface of graphite particles. The mechanical interlock function between the nickel plating layer and graphite is 
strong [13]. Furthermore, after hot pressing sintering process, graphite particles can be partly dissolved in the crystal lattice of nickel in the form of elements due to the high temperature. This process turns the simple mechanical interlock between nickel and graphite into a solid solution bond with gradient variation, and the interface between the two is strong [38]. The nickel layer and the copper in the matrix are mutually illimitably soluble and form a solid solution with face-centered cubic structure. A two-layer interface model is formed between graphite and matrix materials, namely, graphite-nickel matrix. Each layer of the interface is relatively solid, and the graphite is tightly bound to the matrix by nickel.

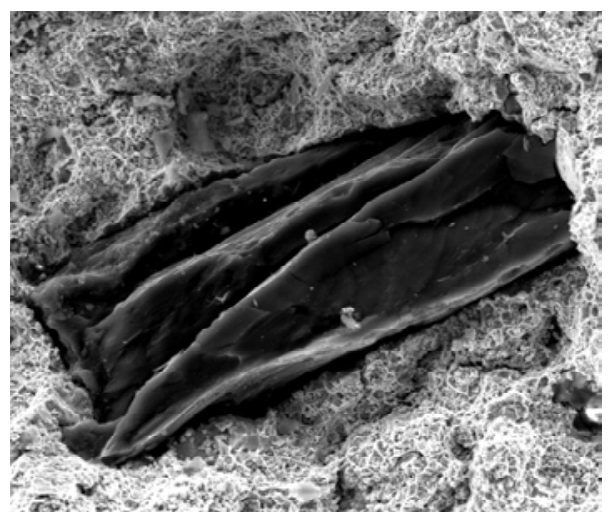

$a$

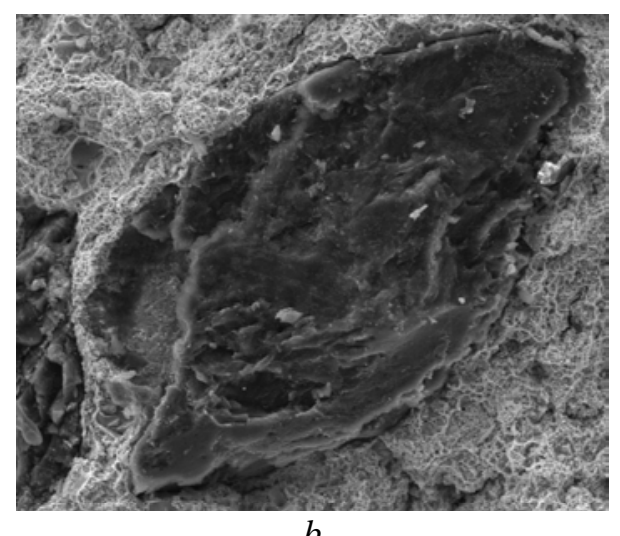

$b$

Fig. 1. SEM images of the interface between graphite and matrix: sample $8(a), 10(b) ; \times 500$.

\section{Effect of graphite on the physical properties of the matrix}

The values for samples 1-5 in Fig. 2 show that the Rockwell hardness and bending strength of the matrix continuously decreased with the increase in graphite content. Figure 1, $a$ shows that the binding force between graphite powder and the matrix is very weak. In addition, the graphite particles have low strength and are in the soft phase form in the matrix which can lead to cracks or pores, thus reducing the hardness and strength of the matrix [39].

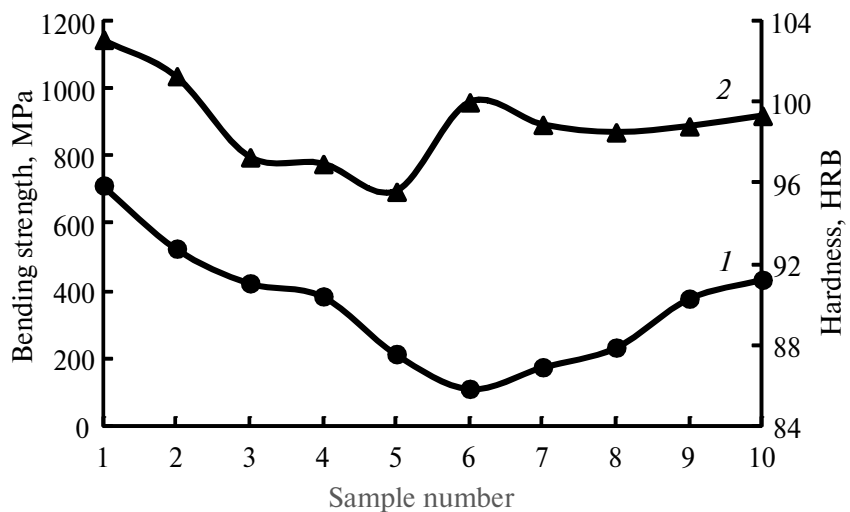

Fig. 2. Hardness (1) and bending strength (2) of matrix.

The values for samples 3 and 6-8 shown in Fig. 2 demonstrate that with the decrease in graphite granularity, the Rockwell hardness of the sample gradually increases, whereas the bending strength gradually decreases. The Rockwell hardness 
is obtained according to the indentation depth in the surface of the sample. Research shows that the indentation range is approximately 10 times more than the indentation depth [39]. If a soft phase exists in the indentation range, then the indentation depth will increase, that is, the hardness decreases. Large graphite particles in the indentation range lead to large indentation depth and low Rockwell hardness. Therefore, with the decrease in graphite granularity, the hardness of the sample is increased. Graphite brings pores or cracks into the matrix, which not only cause stress concentration but also reduce the effective force area of sample resistance to external force, thus reducing the stress that the sample can bear. When the graphite content is certain, a small granularity leads to additional cracks and pores; a small effective force area of the sample resistance to external force results in low bending strength.

The values for samples 8-10 in Fig. 2 show that the hardness and bending strength of the sample increase after graphite surface metallization. Graphite is added to the diamond bit matrix to create self-lubricating composite materials, the overall performance of which is affected by the poor physical and chemical compatibility between graphite and matrix materials. In the process of sintering pure graphite with matrix material, the matrix particles are only softened and partially melted. Therefore, completely covering the graphite particles with low surface energy is difficult. The interface structure of the two is loose, and the interfacial bonding strength is low; hence, the interface can be easily cracked and expanded by external forces, which leads to the decrease in sample strength. After surface metallization, physical and chemical compatibility between graphite and matrix improved, and interfacial bonding strength increased; thus, the overall performance of the self-lubricating composite material improved. That is, the surface metallization of graphite improved the bending strength of the composite material. Increasing the interfacial bonding strength between graphite and matrix barely affected composite hardness but reduced the gap between nickel-plated graphite and matrix; that is, pore volume in the matrix decreased and hardness increased.

\section{Self-lubricating mechanism of graphite and matrix composites}

After friction and wear test of samples 2-10 and granite, a ring of black circle is observed on the granite surface. This black circle is the running track of the sample, and the tactile feeling is greasy, thereby indicating the presence of graphite coating. A considerable amount of friction heat is produced when the composite material and granite wears and tears each other, and the coefficient of thermal expansion of graphite and matrix are very different. Consequently, graphite is extruded by thermal stress and coats the friction surface. In addition, during the friction, graphite encounters friction and extrusion, which can make graphite fall off from the composite material and coats on the friction surface. When a considerable amount of graphite is coated on the friction surface, a layer of lubricating film with a low shear modulus is formed [40].

From the energy spectrum analysis of the friction surface of sample 5 in Fig. 3, a small amount of graphite is present on the sample friction surface, approximately 13-15\%. This finding indicates that the combination of graphite lubricating film and matrix material is poor, but graphite combination with granite is excellent. Therefore, when the lubricating film is formed on the granite surface, only a slight graphite abrasion exists on the matrix surface. When a complete graphite lubricant film is formed on the granite surface, the contact state of the friction pair turns immediate contact between local minor region of matrix and granite into contact 
between matrix and soft and thin graphite lubricant film. The actual contact area of the friction pair increases and the pressure decreases; hence, the matrix and the granite only demonstrate elastic deformation, but no abrasive or adhesive wear is present. Graphite has a lamellar structure, and its intermolecular bonding force is very small. The shear strength of graphite is very low; therefore, slipping easily occurs. Consequently, the graphite can slip between the friction pair, and the sliding deformation occurs nearly exclusively within the graphite lubrication film; hence, the deformation of the matrix material is very small. At this point, the wear of matrix and granite is very slight; thus, graphite is anti-friction. When the graphite content is small, it can only form an incomplete lubricating film or a small graphite grinding dust on the friction surface, which also possesses anti-wear performance.

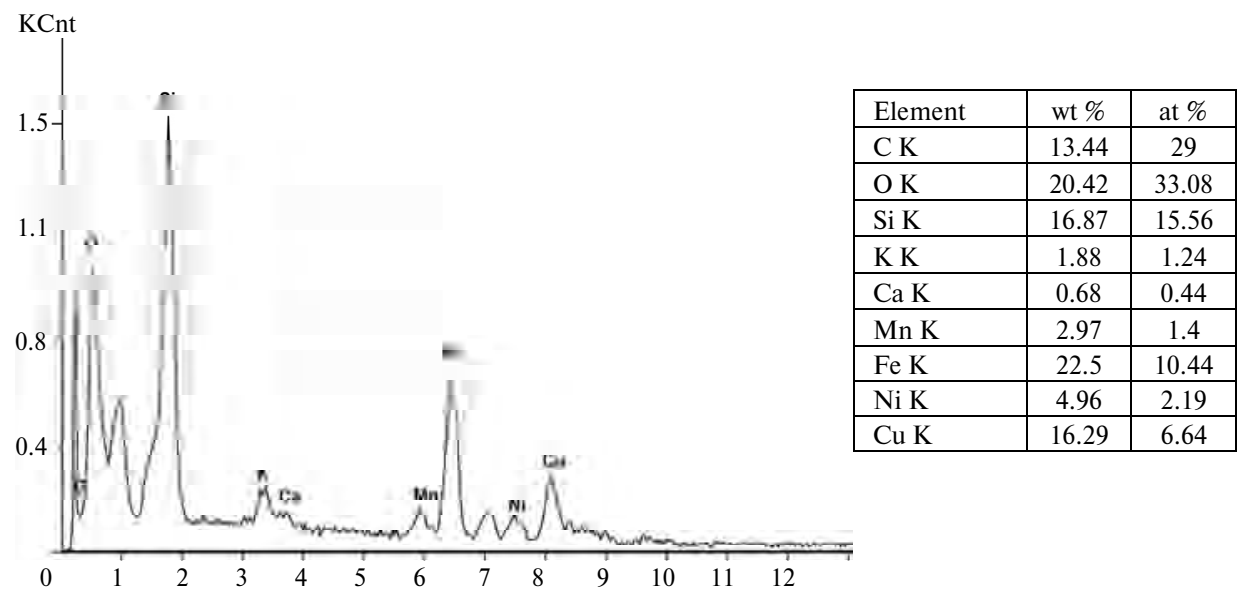

Fig. 3. Energy spectrum analysis of the friction surface of sample 5.

When friction and wear test of the sample are worn, the graphite in the sample is extruded by thermal and mechanical stresses and is then coated on the friction surface. Consequently, graphite lubricating film is formed, and the friction coefficient of the friction pair is reduced. When the lubrication film is destroyed, the friction coefficient rises again, and the sample continues to be worn; therefore, the new graphite is extruded to form a new lubricating film. During the entire process of the friction and wear test, the formation, breakage, shedding, and regeneration of the graphite lubrication film are continuously circulated.

\section{Effect of graphite on the dry tribological properties of the matrix}

The values for samples 1-5 in Fig. 4 show that the friction coefficient of friction pairs decreases with increase in graphite in the matrix, whereas the abrasion loss of the sample decreases first and then increases. When the graphite content in the sample is low, the lubrication film formed on the friction surface is incomplete, and the newly formed lubrication film cannot catch up with the shedding of the old one. Friction and wear still occur between the sample and granite; hence, the friction coefficient average of the entire process and the abrasion loss of the sample are large. When the graphite content in the sample is moderate, the lubrication film formed on the friction surface is complete, and the newly formed lubrication film catches up with the shedding of the old one. The entire friction and wear process always occurs within the graphite lubricant film; hence, the friction coefficient average and the abrasion loss of the sample decrease. 
When the graphite content in the sample is extremely large, the friction and wear also occur within the graphite lubricant film; hence, the friction coefficient average is slightly reduced. However, the holes due to graphite loss increase; therefore, the actual contact area between granite and matrix decreases, and the intensity of pressure increases, thereby consequently increasing the abrasion loss of the sample.

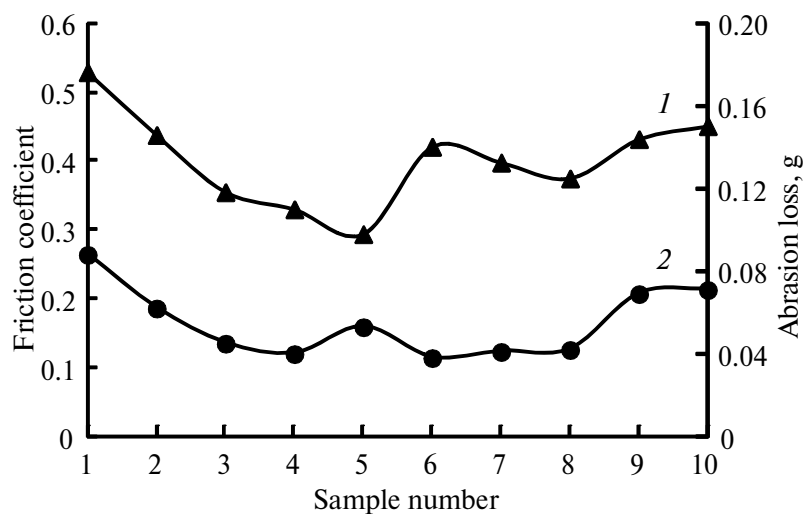

Fig. 4. Friction coefficient (1) and abrasion loss (2) of the matrix.

The values for samples $6-8$ and 3 in Fig. 4 show that with the decrease in graphite granularity, the friction coefficient of friction pair gradually decreases, whereas the abrasion loss of matrix increases. This finding can be attributed to the smaller density graphite than that of matrix, thereby making it difficult to realize uniform material mixing. When the graphite content in the matrix is certain, the small graphite particle leads to uniform graphite distribution in the matrix; forming a complete lubrication film is easy when the friction coefficient is small. However, when the graphite particles are extremely small, many holes due to graphite loss uniformly distribute on the matrix surface, and the intensity of pressure increases, thus increasing the abrasion loss of the sample.

The values for samples $8-10$ in Fig. 4 show that the friction coefficient of friction pair and the abrasion loss of matrix both increase after surface metallization of graphite. This result can be attributed to the strong interface force between matrix and nickel-plated graphite. Moreover, falling off from the matrix is difficult for graphite. Consequently, the lubricating film formed in the friction pair surface is incomplete, and the friction coefficient of friction pair and the abrasion loss of matrix are both large.

\section{Wear morphology analysis of the sample}

Figure 5 shows the SEM figure of the wear morphology of samples 1 and 5 . In Fig. 5, the main wear form of sample 1 is adhesive wear, and the main wear form of sample 5 is abrasive wear. The surface temperature of sample 1 without graphite sharply increases during the process of friction with the granite, and severe plastic deformation occurs on the matrix. The matrix is then daubed by the friction force. Graphite falls off from the matrix when the sample 5 with 10 vol \% of graphite rub and wear with granite, and then become into lubricating film on the surface of the friction pair. Consequently, the friction coefficient of the friction pair decreases, and the increase in friction surface temperature is controlled. Therefore, plastic deformation of the matrix is small, and the main wear formed is abrasive wear due to hard particle in granite powder. 


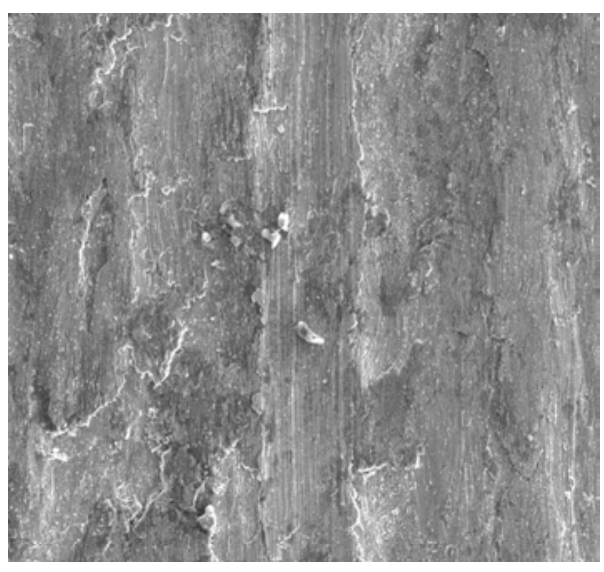

$a$

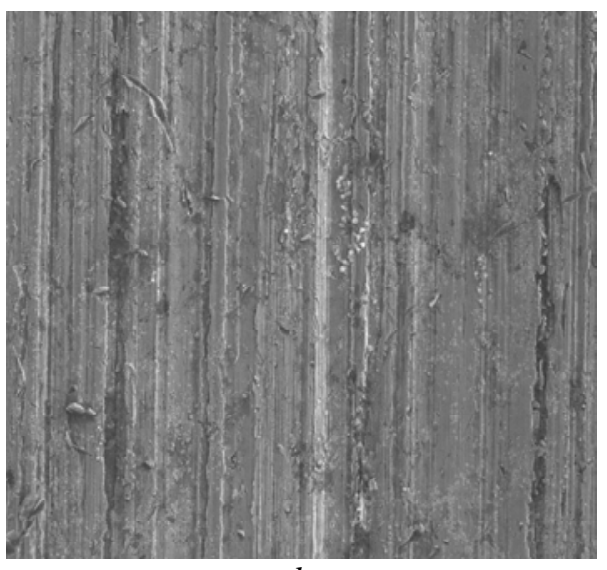

$b$

Fig. 5. SEM images of the sample wear morphology: sample $1(a), 5(b) ; \times 300$.

\section{Effect of graphite on the dry tribological properties of the working layer}

Figure 6 is the friction coefficient curve recorded by the software of the testing machine in the process of friction and wear test. The $x$-coordinate is the sampling point, and the $y$-coordinate is friction coefficient. It shows that the friction coefficient is large and repeatedly changes at first; the friction coefficient then stabilizes and become small after certain period. Figure 7 shows the scanning electron micrograph of the diamond on the friction surface of the working layer after the friction and wear test. From the figure, numerous grooves and cracks can be observed on the diamond surface, and the diamond is broken and dull, thereby indicating that the diamond completely failed. At first, the diamonds appear and break the granite; hence, the friction coefficient significantly fluctuates. Simultaneously, the temperature of the friction interface sharply increases, and the performance of diamond sharply decreases, thereby producing hard particle in granite-powder groove on the diamond surface. Cracks perpendicular to the friction direction occur on the diamond surface by tensile stress. The diamonds are then broken and become dull by normal load and friction, and severe thermal injury finally occurs. Owing to the low abrasiveness of granite, the abrasion loss of matrix is small, and the damaged diamond cannot fall off but still remained on the sample friction surface. In this way, friction and wear only occur between a few diamonds and granite; therefore, the contact area and friction coefficient are considerably reduced.

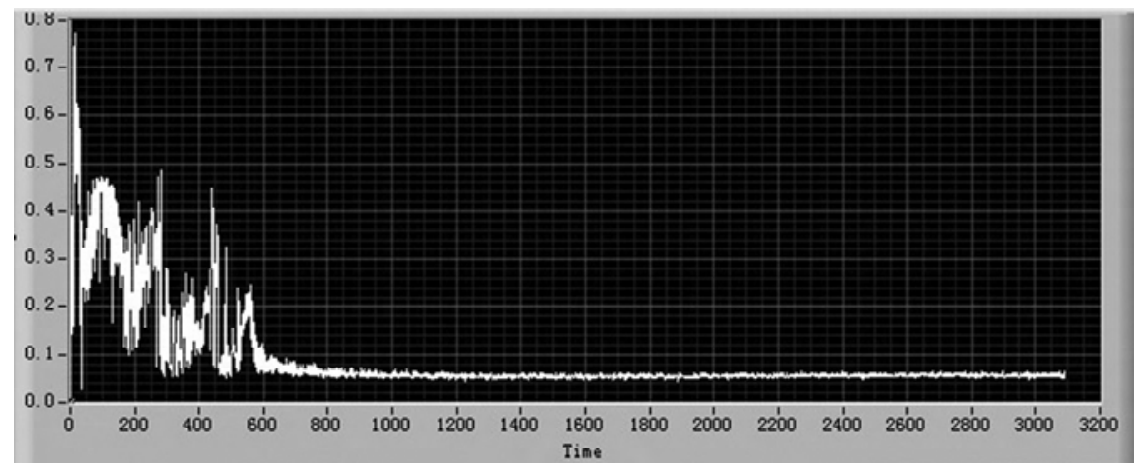

Fig. 6. Friction coefficient curve of working layer sample. 

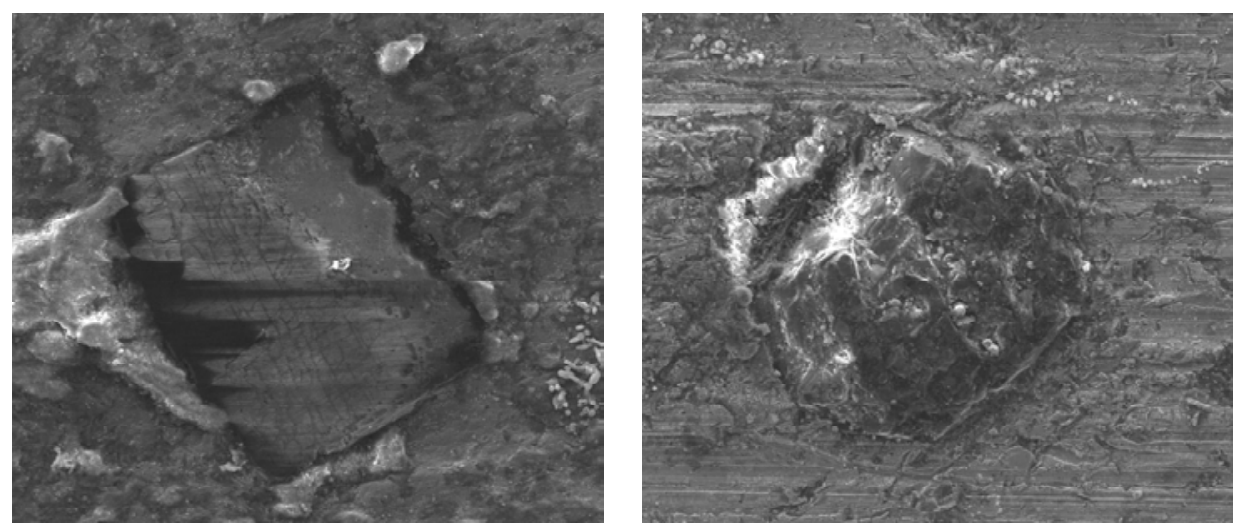

Fig. 7. SEM image of the failure diamond.

In the initial stage of the friction and wear test, the diamond breaks the granite, and the resulting granite powder wears the matrix. Consequently, the graphite in the matrix is extruded by thermal and mechanical stresses. The binding force between graphite and matrix materials is weak, and the surface of granite is continuously broken by diamond. Therefore, forming a lubricating film on the surface of either is difficult for graphite. Moreover, graphite can form a lubricating film on the diamond surface [41] and convert the contact between diamond and granite to the contact between lubrication film and granite. When the graphite lubrication film is damaged, the diamond continues to contact the granite. The addition of graphite can prolong the time of diamond cutting granite, namely the life of diamond.

The diamond lifetime of every sample can be calculated by the curve diagram of its friction coefficient. As shown in Fig. 6, friction coefficient is large and repeatedly changes from 0 to 600 sampling point, which is the period diamond cut granite, namely the life of diamond. The calculation formula is as follows:

$$
t=\frac{n T}{N}
$$

where $t$ is the life of diamond, min; $\mathrm{n}$ is the number of sampling points during diamond cutting granite; $T$ is the testing time of the friction and wear test, which is 10 min; and $N$ is the total number of sampling points during the friction and wear test.

The experimental results are shown in Fig. 8, with the increase in graphite content, the graphite lubricant film on the diamond surface is complete, and its regeneration speed increases. Thus, the chances of wear between diamond lifetime and granite are reduced, and the lifetime of diamond increases. With the decrease in graphite granularity, the graphite distribution in the sample is uniform, and the graphite lubrication film on the diamond surface is complete, thereby improving the lifetime of diamond. The force between matrix and nickel-plated graphite is strong, and falling off from the matrix surface is difficult for graphite. Consequently, the lubricating film formed on the surface of the diamond is incomplete, and the lifetime of diamond is shortened.

\section{CONCLUSIONS}

The results of this study reveal that the addition of graphite improved the dry friction properties of the bit and the lifetime of diamond in the working layer but 
reduced the hardness and bending strength of the matrix. With the increase in graphite, the hardness, bending strength, and friction coefficient of matrix gradually decreased, but its abrasion loss decreased first and then increased. By contrast, the lifetime of diamond in the working layer gradually increased. With the decrease in graphite granularity, the bending strength and friction coefficient of matrix gradually decreased, whereas the hardness, abrasion loss of matrix, and the lifetime of diamond in the working layer gradually increased. After surface metallization of graphite, the hardness, bending strength, friction coefficient, and abrasion loss of matrix were increased, whereas the lifetime of diamond in the working layer was decreased.

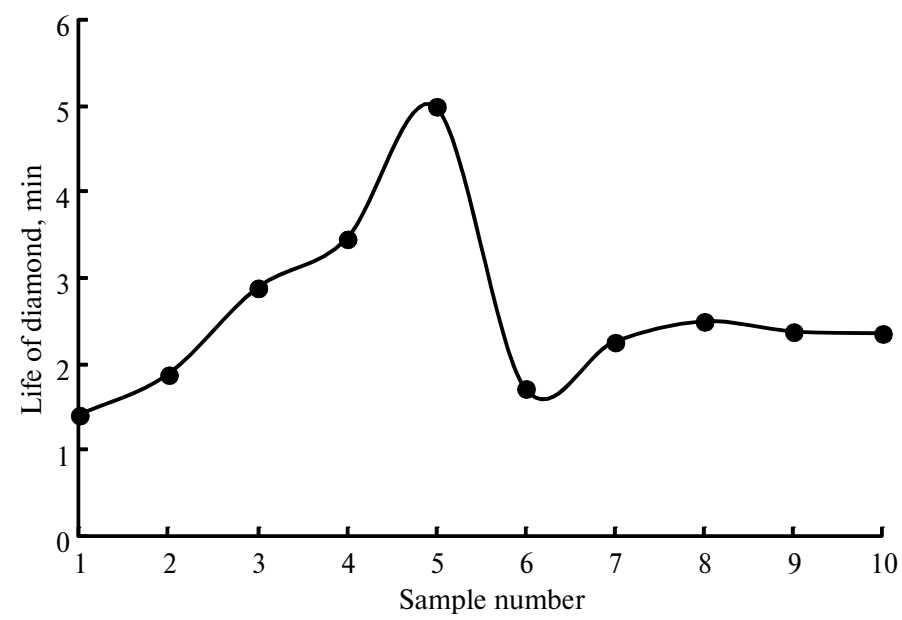

Fig. 8. Diamond lifetime of working layer.

The properties of the diamond bit, including hardness, bending strength, abrasion resistance, friction coefficient, etc., should be matched with the strata drilled. In this study, granite was selected as the drilling object. The optimal method was to add 2.4 wt \% nickel-plated graphite with a particle size of 100/120 mesh in diamond bit. With this method, hardness and bending strength of diamond bit reduced a little, but dry friction properties of the diamond bit improved, and the life of diamond improved remarkably.

Для зменшення термічного пошкодження алмазного інструмента при бурінні без охолоджуючої рідини в якості твердого мастила використовували графіт, його додавали до матеріалу матриці інструмента для зменшення коефіцієнта тертя $i$ виділення тепла. Досліджено вплив вмісту, зернистості і металізації поверхні графіту на механічні властивості та умови сухого тертя матриці, а також часу утримання алмазу в робочому шарі. Результати показали, щуо твердість, міцність на вигин $і$ коефіцієнт тертя матрииі поступово зменшуються зі збільшенням концентрації графіту. Проте втрати від дї тертя спочатку зменшувалися, а потім збільшувалися, а час утримання алмазу в робочому шарі поступово збільшувався. Зі зменшенням гранулярності графіту міциість на вигин і коефіцієнт тертя матриці поступово змениувалися, тоді як твердість, втрати від тертя матриці і час утримання алмазу в робочому шарі поступово збільшувалися. Після металізачї поверхні графіту твердість, мічність на вигин, коефіцієнт тертя та втрати від тертя матриці зростали, а час утримання алмазу в робочому шарі зменшувався. Це дослідження закладає основу для буріння без використання води.

Ключові слова: графіт, ромб, механічні властивості, властивості сухого тертя, час утримання алмазу. 
Для уменьшения термического повреждения алмазного инструмента при бурении без охлаждающей жидкости в качестве твердой смазки использовали графит, его добавляли к материалу матриць инструмента для уменьшения коэффициента трения и выделение тепла. Исследовано влияние содержания, зернистости и металлизации поверхности графита на механические свойства и условия сухого трения матриць, а также времени удержания алмаза в рабочем слое. Результаты показали, что твердость, прочность на изгиб и коэффиичент трения матрицы постепенно уменьшаются с увеличением концентрации графита. Однако потери от действия трения сначала уменьшались, а затем увеличивались, а время удержания алмаза в рабочем слое постепенно увеличивалось. С уменьшением гранулярности графита прочность на изгиб и коэффициент трения матрицы постепенно уменьшались, тогда как твердость, потери от трения матрицы и время удержания алмаза в рабочем слое постепенно увеличивались. После металлизации поверхности графита твердость, прочность на изгиб, коэффициент трения и потери от трения матриць росли, а время удержания алмаза в рабочем слое уменьшался. Это исследование закладывает основу для бурения без использования воды.

Ключевые слова: графит, ромб, механические свойства, свойства сухого трения, время удержания алмаза.

1. Fan Y., Zhang J.S, Gao Y., Wu F., Liu B.W. The influence of graphite particle size on friction and wear properties of copper-ferrous matrix friction materials. Tribology. 2000. Vol. 6, no. 20. P. 475-477.

2. Kong Xiao-li, Liu Yong-bing, Lu You, Huo Fu-xiang. P/M metal-matrix high-temperature solid self-lubricating materials. Powder Metall. Technol., 2001. Vol. 2, no. 19. P. 86-92.

3. Zacny K.A., Cooper G.A. Investigation of diamond-impregnated drill bit wear while drilling under Earth and Mars conditions. J. Geophys. Res.-Planets, 2004. Vol. 109, no. E7. P. E7SE10S.

4. Shaji S., Radhakrishnan V. Application of solid lubricants in grinding:investigations on graphite sandwiched grinding wheels. Machining Sci. Technol., 2003. Vol. 1, no. 7. P. 137-155.

5. Bagde Pranay, Sapate S.G., Khatirkar R.K. Friction and abrasive wear behaviour of $\mathrm{Al}_{2} \mathrm{O}_{3}-$ $13 \mathrm{TiO}(2)$ and $\mathrm{Al}_{2} \mathrm{O}_{3}-13 \mathrm{TiO}(2)+\mathrm{Ni}$ graphite coatings, Tribology Int., 2018. Vol. 121. P. 353372.

6. Zhen Jinming, Zhu Shengyu, Cheng Jun. Influence of graphite content on the dry sliding behavior of nickel alloy matrix solid lubricant composites, Tribology Int., 2017. Vol. 114. P. 322-328.

7. Venu Gopal A., Venkateswara Rao P. Performance improvement of grindingof SiC using graphite as a solid lubricant. Mater. Manuf. Proces. 2004. Vol. 2, no. 19. P. 177-186.

8. Tan Hui, Wang Shuai, Cheng Jun. Tribological properties of Al-20Si-5Fe-2Ni-graphite solid-lubricating composites. Tribology Int. 2018. Vol. 121. P. 214-222.

9. Zouari M., Kharrat M., Dammak M. Wear and friction analysis of polyester coatings with solid lubricant. Surf. Coat. Technol. 2010. Vol. 16-17. no. 204. P. 2593-2599.

10. Kuk E., Kim G., Lee C. Effects of solid lubricant content and size on the tribology of NiCr$\mathrm{Cr}_{2} \mathrm{O}_{3}$-Ag composites. J. Ceram. Process. Res. 2005. Vol. 2, no. 6. P. 95-100.

11. Chen Baiming, Bi Qinling, Yang Jun. Tribological properties of solid lubricants (graphite, hBN) for Cu-based P/M friction composites. Tribology Int. 2008. Vol. 12, no. 41. P. 11451152.

12. Singh Sachin, Tyagi Mukti, Seshadri Geetha. Effect of gamma radiation on graphite - PTFE dry lubrication system. Radiat. Phys. Chem. 2017. Vol. 141. P. 213-219.

13. Xie Lanlan, Pan Bingsuo, Duan Longchen. Study on the technique of nickel electroplating on graphite powders. Diamond Abrasiv. Eng. 2011. Vol. 183, no. 31. P. 23-26.

14. Mechnyk V.A. Diamond-Fe-Cu-Ni-Sn composite materials with predictable stable characteristics. Mater. Sci. 2013. Vol. 48, no. 5. P. 591-600.

15. Kolodnits'kyi V.M., Bagirov O.E. On the structure formation of diamond-containing composites used in drilling and stone-working tools (A Review). J. Superhard Mater. 2017. Vol. 39, no. 1. P. 1-17.

16. Mechnik V.A., Bondarenko N.A., Kuzin N.O., Lyashenko B.A. The role of the structure formation in forming the physicomechanical properties of composites of the diamond-(FeCu-Ni-Sn) system. J. Friction Wear. 2016. Vol. 37, no. 4. P. 377-384.

17. Novikov M.V., Mechnyk V.A., Bondarenko M.O., Lyashenko B.A., Kuzin M.O. Composite materials of diamond-(Co-Cu-Sn) system with improved mechanical characteristics. Part 1. 
The influence of hot re-pressing on the structure and properties of diamond-(Co-Cu-Sn) composite. J. Superhard Mater. 2015. Vol. 37, no. 6. P. 402-416.

18. Mechnik V.A. Production of diamond- $(\mathrm{Fe}-\mathrm{Cu}-\mathrm{Ni}-\mathrm{Sn})$ composites with high wear resistance. Powder Metall. Metal Ceram. 2014. Vol. 52, no. 9. P. 577-587.

19. Gevorkyan E., Mechnik V., Bondarenko N., Vovk R., Lytovchenko S., Chishkala V., Melnik O. Peculiarities of obtaining diamond-(Fe-Cu-Ni-Sn) composite materials by hot pressing. Funct. Mater. 2017. Vol. 24, no. 1. P. 31-45.

20. Bondarenko N.A., Zhukovsky A.N., Mechnik V.A. Analysis of the basic theories of sintering materials. 1. Sintering under isothermal and nonisothermal conditions (A review). J. Superhard Mater. 2005. Vol. 27, no. 6. P. 1-13.

21. Bondarenko N.A., Mechnik V.A. The influence of transition area diamond-matrix on wear resistance and operation properties of drilling tool produced by ISM. SOCAR Proc. 2011. No. 2. P. 18-24.

22. Novikov N.V., Bondarenko N.A., Zhukovsky A.N., Mechnik V.A. Influence of the diffusion and chemical reactions on the structure and properties of drilling inserts. 1. Kinetic description of the $\mathrm{C}_{\text {diamond }}-\mathrm{WC}-6 \mathrm{Co}$ and $\mathrm{C}_{\text {diamond }}-\left(\mathrm{WC}-6 \mathrm{Co}-\mathrm{CrB}_{2}-\mathrm{W}_{2} \mathrm{~B}_{5}\right)$ systems. Phys. Mesomechan. 2005. Vol. 8, no. 2. P. 99-106.

23. Bondarenko N.A., Novikov N.V., Mechnik V.A., Oleinik G.S., Vereshchaka V.M. Structural features of diamond-WC-6Co superhard composites that differ in wear resistance. J. Superhard Mater. 2004. Vol. 26, no. 6. P. 1-13.

24. Novikov M.V., Mechnik V.A., Bondarenko M.O., Lyashenko B.A., Kuzin M.O. Composite materials of diamond-(Co-Cu-Sn) system with improved mechanical characteristics. Part 2. The influence of $\mathrm{CrB}_{2}$ additive on the structure and properties of diamond-(Co-Cu-Sn) composite. J. Superhard Mater. 2016. Vol. 38, no. 3. P. 155-168.

25. Mechnik V.A. Effect of Hot Recompaction Parameters on the Structure and Properties of Diamond-(Fe-Cu-Ni-Sn-CrB 2 ). Composites, Powder Metall. Metal Ceram. 2014. Vol. 52, no. 11-12. P. 709-721.

26. Mechnyk V.A. Regularities of structure formation in diamond-Fe-Cu-Ni-Sn-CrB ${ }_{2}$ systems. Mater. Sci. 2013. Vol. 49, no. 1. P. 93-101.

27. Bondarenko M.O., Mechnik V.A., Suprun M.V. Special features of the shrinkage and its rate in the Cdiamond-Fe-Cu-Ni-Sn-CrB $\mathrm{C}_{2}$ system during hot pressing of presureess-sintered compacts. J. Superhard Mater. 2009. Vol. 31, no. 4. P. 232-240.

28. Sidorenko D.A., Zaitsev A.A., Kirichenko A.N., Levashov E.A., Kurbatkina V.V., Loginov P.A., Rupasov A.I., Andreev V.A. Interaction of diamond grains with nanosized al loying agents in metal-matrix composites as studied by Raman spectroscopy. Diamond Relat. Mater. 2013. Vol. 38, no. 9. P. 59-62.

29. Mechnik V.A., Bondarenko N.A., Kuzin N.O., Gevorkian E.S. Influence of the addition of vanadium nitride on the structure and specifications of a diamond-( $\mathrm{Fe}-\mathrm{Cu}-\mathrm{Ni}-\mathrm{Sn})$ composite system. J. Friction Wear. 2018. Vol. 39, no. 2. P. 108-113.

30. Aleksandrov V.A., Alekseenko N.A., Mechnik V.A. Investigation of force and energy parameters of the cutting granite with diamond disk saws. Sov. J. Superhard Mater. 1984. Vol. 6, no. 6. P. 35-39.

31. Dutka V.A., Kolodnitsky V.M., Melnychuk O.V., Zabolotny S.D. Mathematical model for thermal processes occurring in the interaction between rock destruction elements of drilling bits and rock mass. J. Superhard Mater. 2005. Vol. 27, no. 1. P. 61-70.

32. Aleksandrov V.A., Mechnik V.A. The effect of diamond heat conductivity and heat transfer coefficient upon contact temperature and wear of cutting discs. J. Frict. Wear. 1993. Vol. 14, no. 6. P. 1115-1117.

33. Aleksandrov V.A., Zhukovsky A.N., Mechnik V.A. Temperature and wear of inhomogeneous diamond wheel under convective heat transfer. Part 1. J. Frict. Wear. 1994. Vol. 15, no. 1. P. 27-35.

34. Aleksandrov V.A., Zhukovsky A.N., Mechnik V.A. Temperature and wear of inhomogeneous diamond wheel under convective heat transfer. Part 2. J. Frict. Wear. 1994. Vol. 15, no. 2. P. 196-201.

35. Zhukovskii A.N., Maistrenko A.L., Mechnik V.A., Bondarenko N.A. The stress-strain state of the bonding around the diamond grain exposed to normal and tangent loading components. Part 1. Model. J. Frict. Wear. 2002. Vol. 23, no. 3. P. 146-153.

36. Zhukovskii A.N., Maistrenko A.L., Mechnik V.A., Bondarenko N.A. Stress-strain state of the matrix around the diamond grain exposed to the normal and tangent loading components. Part 2. Analysis. J. Frict. Wear. 2002. Vol. 23, no. 4. P. 393-396. 
37. Sveshnikov I. A and Kolodnitskiy V. N., Optimization of carbide cutter arrangement in a drill bit body. J. Superhard Mater. 2006. Vol. 28, no. 4. P. 64-68.

38. NIU Mingyuan: Study on Design and Wear Characteristics of Heterogeneous Diamond Bit Matrix Structural Unit. China Univer. Geosci., 2010.

39. Jiang Xiaosong, Liu Wanxia, Li Yanjun. Microstructures and mechanical properties of $\mathrm{Cu} / \mathrm{Ti}_{3} \mathrm{SiC}_{2} / \mathrm{C} /$ graphene nanocomposites prepared by vacuum hot-pressing sintering. Compos. Part B-Eng. 2018. Vol. 141. P. 203-213.

40. Zhou Liming, You Qianbing, Xiong Ji. Dry wear behaviors of graphite/cermet selflubricating composite under different sliding conditions and simulation of temperature field. Int. J. Refract. Metals Hard Mater. 2018. Vol. 73. P. 85-90.

41. Miao Qing, Ding Wenfeng, Fu Dengkui. Influence of graphite addition on bonding properties of abrasive layer of metal-bonded CBN wheel. Int. J. Adv. Manufact. Technol. 2017. Vol. 5-8, no. 93. P. 2675-2684.

Received 17.05.18

Revised 25.06.18

Accepted 25.06.18 